\title{
IMPLEMENTASI WEBINAR TERHADAP SIKAP SADAR KEAMANAN KIMIA MAHASISWA
}

\author{
Nelius Harefa ${ }^{1^{*}}$, Sumiyati ${ }^{2}$, Leony Sanga Lamsari Purba ${ }^{3}$ \\ *corresponding author: nelius.harefa@uki.ac.id \\ ${ }_{1,2,3}$ Universitas Kristen Indonesia
}

\begin{abstract}
Chemical security is one of the important indicators in the chemistry learning process. It is important for students to explore their knowledge of the conscious attitude of chemical security. Insecure attitudes will cause problems for these students, others, and the environment. Many sources can be used to foster a conscious attitude to chemical security, one of which is by participating in a website-based seminar (webinar). Knowledge formed at the webinar is a reference for respondents in choosing the option of choice in the statement provided. Data collection is done by giving questionnaires to respondents. The questionnaire contained nine statements related to chemical security awareness. Each statement is given five choice options with reference to the Likert scale system. Based on respondents' data, it was seen that $42.7 \%$ of respondents chose the basic knowledge option in the chemical security statement, $28.1 \%$ chose the option above basic knowledge, $26.9 \%$ chose the intermediate knowledge option, and the other $2.3 \%$ chose the advanced knowledge option. While the expert knowledge option which is the highest value option is not chosen by the respondent. From these data, it shows that the respondent's chemical security attitude is classified as low.
\end{abstract}

Keywords: Chemical Security, Webinar

\begin{abstract}
ABSTRAK
Keamanan kimia merupakan salah satu indikator penting dalam proses pembelajaran kimia. Penting bagi pebelajar untuk menggali pengetahuannya terhadap sikap sadar keamanan kimia. Sikap yang tidak aman akan menyebabkan masalah bagi pebelajar tersebut, orang lain, dan lingkungan. Banyak sumber yang dapat digunakan untuk menumbuhkan sikap sadar keamanan kimia, salah satunya dengan berpartisipasi pada acara seminar berbasis website (webinar). Pengetahuan yang terbentuk pada acara webinar menjadi acuan responden dalam memilih opsi pilihan pada pernyataan yang telah disediakan. Pengumpulan data dilakukan dengan memberikan angket pada responden. Angket tersebut memuat sembilan pernyataan terkait sikap sadar keamanan kimia. Masing-masing pernyataan diberi lima opsi pilihan dengan mengacu pada sistem skala Likert. Berdasarkan data responden terlihat bahwa $42,7 \%$ responden memilih opsi pengetahuan dasar pada pernyataan keamanan kimia, 28,1\% memilih opsi diatas pengetahuan dasar, 26,9\% memilih opsi pengetahuan menengah, dan 2,3\% lainnya memilih opsi pengetahuan mahir. Sedangkan opsi pengetahuan ahli yang merupakan opsi dengan nilai tertinggi tidak dipilih oleh responden. Dari data tersebut, menunjukkan bahwa sikap keamanan kimia responden tergolong rendah.
\end{abstract}

Kata Kunci: Keamanan Kimia, Webinar 


\section{PENDAHULUAN}

Seminar berbasis web (webinar) merupakan inovasi baru penyelenggaraan seminar yang umumnya berlangsung secara langsung (tatap muka). Penyelenggaraan seminar berbasis web dapat mengakomodasi berbagai pihak tanpa terpisahkan oleh waktu, jarak, dan biaya. Dengan demikian, webinar sangat cocok di era revolusi industri 4.0 yang serba digital. Seminar memiliki peranan penting terhadap perkembangan ilmu pengetahuan. Seminar merupakan sarana berbagi ilmu pengetahuan dari berbagai latar belakang pendidikan, latar belakang profesi keilmuwan, serta latar belakang pemateri dan peserta yang heterogen. Seminarnya umumnya membahas isu-isu penting, isu-isu terkini, maupun isu-isu yang sedang terjadi. Dalam pembelajaran kimia, seminar memiliki peranan penting dalam perkembangannya sebagai keilmuwan. IImu kimia yang sangat dinamis membutuhkan/memerlukan sumber informasi yang beragam baik dari para ahli, penggiat ilmu kimia, penggiat pendidikan, dan kimia itu sendiri. Salah satu isu yang sangat penting untuk digelorakan oleh stakeholder ilmu kimia maupun pendidikan kimia adalah isu keamanan kimia. Keamanan kimia merupakan syarat mutlak bagi siapapun yang berkecimpung dalam ilmu kimia tersebut. Maraknya penyalahgunaan dan masalah yang timbul akibat kurangnya sikap aman kimia menimbulkan keresahan dalam masyarakat.

Danjtie (2016) dalam penelitiannya menyebutkan bahwa terdapat perbedaan signifikan antara pengetahuan, sikap, dan praktik keselamatan dan kesehatan kerja laboratorium kimia. Keselamatan dan kesehatan kerja laboratorium kimia merupakan salah satu indikator sikap keamanan kimia. Peneliti menjelaskan bahwa sikap merupakan unsur yang paling sulit untuk diubah. Pengetahuan yang baik dari seorang mahasiswa tidak menjamin dia memiliki sikap keselamatan dan kesehatan kerja laboratorium. Demikian pula halnya dengan mahasiswa yang memiliki keterampilan praktik yang baik, praktik yang baik tidak dapat dijadikan acuan untuk menilai bahwa seorang mahasiswa akan bersikap baik juga. Dari ketiga unsur tersebut, unsur sikap merupakan unsur yang sangat sulit dianalisa. Pengetahuan dapat digali oleh mahasiswa dengan membaca, konsultasi dengan teman sejawat, konsultasi dengan tenaga pendidik, dan sebagainya. Demikian halnya dengan unsur praktik, unsur ini menjadi unsur yang sangat mudah dipelajari di era digital seperti sekarang ini. Berbagai video pembelajaran dapat dicari dan dikembangkan sendiri oleh mahasiswa. Sedangkan unsur sikap, tidak dapat dipelajari dari siapapun melainkan harus terbentuk dengan sendirinya.

Sangi (2018) mengungkapkan bahwa keselamatan dan keamanan laboratorium harus menjadi prioritas dalam pembelajaran yang bersifat praktik. Laboratorium yang merupakan tempat berlatih secara langsung menjadi sangat krusial bagi praktikannya. 
Keselamatan dan keamanan laboratorium merupakan syarat mutlak dan indikator utama terhadap laboratorium. Harefa (2018) menyatakan bahwa pembelajaran di laboratorium dapat meningkatkan keterampilan pemecahan masalah siswa maupun motivasi siswa tersebut. Dengan banyaknya manfaat yang diperoleh dari pembelajaran berbasis laboratorium, maka keselamatan dan keamanan laboratorium yang baik harus terealisasi.

Bahan kimia memiliki berbagai macam karakter. Beberapa di antaranya mudah meledak, korosif, pengoksidasi, beracun, mudah terbakar, menyebabkan iritasi, dan sebagainya. Karakteristik yang berbeda-beda mengharuskan penggunanya mengetahui karakteristik-karakteristik bahan-bahan kimia tersebut. Kesalahan penanganan akan berakibat fatal bagi pengguna, sarana dan prasarana, masyarakat sekitar, dan lingkungan.

Setelah pengetahuan tentang karakterisitik tersebut, hal lain yang perlu diperhatikan adalah tingkat bahaya yang ditimbulkan suatu bahan kimia. Tingkat bahaya dimaksud difokuskan untuk bahan kimia berwujud cairan yang dikenal dengan konsentrasi. Bahan kimia akan berbeda dengan adanya perbedaan konsentrasi. Perbedaan konsentrasi akan berpengaruh langsung terhadap tingkat bahaya bahan kimia tersebut. Bahan kimia berkonsentrasi rendah umumnya lebih aman dibanding dengan bahan kimia berkonsentrasi tinggi. Namun, tidak selamanya demikian. Beberapa bahan kimia tetap berbahaya bahkan pada konsentrasi rendah sekalipun. Hal ini yang menyebabkan tingkat kompleksisitas penanganan bahan kimia tergolong rumit. Kompleksitas ini mengharuskan penggunanya memiliki beragam keterampilan sehingga keamanan kimia yang baik dapat terwujud.

Keamanan kimia tergolong dalam beberapa bagian. Namun, kriteria keamanan pertama untuk skala laboratorium adalah penyimpanan bahan kimia tersebut. Dengan asumsi bahwa pengantaran bahan kimia ke laboratorium dilakukan oleh profesional yang berasal dari suatu institut yang bertugas memproduksi bahan kimia dimaksud. Penting untuk diperhatikan bahwa penyimpanan bahan kimia sangat krusial, setidaknya ada tiga hal yang sangat dipengaruhi oleh penyimpanan bahan kimia antara lain: kemurnian bahan kimia, tingkat terjadinya bahaya, dan efisiensi penggunaan waktu untuk mencari bahan kimia yang diinginkan. Kemurnian bahan kimia identik dengan sifatnya yang mudah bereaksi. Kesalahan penyimpanan memungkinkan terjadinya reaksi internal antar bahan kimia. Reaksi tersebut menyebabkan bahan kimia tidak pada keadaan murni lagi. Ketidakmurnian bahan kimia akan menyebabkan hasil percobaan/penelitian tidak dapat dipercaya (tidak valid), dengan kata lain percobaan tersebut dapat dikatakan gagal.

Tingkat terjadinya bahaya berkaitan erat dengan sifat bahan kimia yang mudah meledak, mudah terbakar, korosif, dan sebagainya. Kesalahan penyimpanan dapat menyebabkan bahaya yang besar terhadap bahan kimia yang dapat berakibat fatal bagi 
manusia dan lingkungan sekitar. Penggabungan bahan kimia yang salah dapat mengindikasikan terjadinya reaksi yang dapat menyebabkan kelebihan tekanan sehingga terjadi ledakan. Selain terjadinya ledakan, kesalahan penyimpanan juga akan mempengaruhi konsentrasi. Perubahan konsentrasi akan berbanding lurus dengan perubahan penanganan bahan kimia tersebut. Tidak dapat dibayangkan jika asam klorida yang sudah dilabel dengan konsentrasi 3 Molar $(\mathrm{HCl} 3 \mathrm{M}$ ) ternyata telah berubah menjadi $\mathrm{HCl} 6 \mathrm{M}$ (misalnya) akibat kesalahan penyimpanan.

Efisiensi penggunaan waktu untuk mencari bahan kimia yang diinginkan akan sangat berpengaruh terhadap perencanaan suatu percobaan. Penyimpanan yang tidak sesuai akan menyebabkan kesulitan menemukan bahan kimia yang diinginkan. Kesulitankesulitan tersebut akan memerlukan waktu yang lama yang berdampak pada perencanaan percobaan. Bahkan hal yang paling merugikan adalah tidak ditemukannya bahan kimia dimaksud.

Kriteria keamanan kimia yang kedua adalah perlakuan terhadap limbah. Perlakuan terhadap limbah kimia merupakan kriteria keamanan kimia yang krusial. Perlakuan terhadap limbah kimia identik dengan lingkungan. Kesalahan penanganan limbah kimia sudah pasti atau hampir pasti menyebabkan pencemaran lingkungan, baik dalam skala makro, menengah, maupun mikro. Memang tidak secara umum, pencemaran akibat limbah kimia akan menyebabkan masalah yang besar, namun limbah kimia dapat terakumulasi sehingga dapat menyebabkan masalah yang lebih besar dikemudian hari.

Keamanan kimia utama selain perlakuan terhadap bahan kimia adalah prosedur bekerja dengan bahan kimia dan peralatan kimia. Bekerja dengan bahan kimia merupakan salah satu pekerjaan rumit. Bahan kimia yang memiliki karakter yang berbeda-beda tentu akan menentukan bagaimana cara kita bekerja dengan bahan kimia tersebut. Untuk skala laboratorium dasar, ada beberapa yang harus diperhatikan jika bekerja dengan bahan kimia. Pertama, bekerja dengan zat yang toksisitas tinggi, bekerja dengan zat yang toksisitas tinggi harus memiliki prosedur yang jelas, terperinci dan sudah tervalidasi. Zat toksisitas tinggi akan merugikan pengguna laboratorium jika tidak ditangani dengan tepat. Zat yang secara umum beracun ini kemungkinan akan menyebabkan keracunan dan bahkan sampai pada kematian. Kedua, bekerja dengan bahan berbahaya hayati. Bahan-bahan kimia berbahaya hayati merupakan bahan kimia yang sangat ditakuti. Bahan-bahan kimia ini umumnya menyebabkan infeksi dan keracunan. Dengan sifat yang demikian, maka diperlukan perlakuan tambahan untuk bekerja dengan bahan-bahan ini. Perlakuan-perlakuan tersebut antara lain: mengurangi potensi pembentukan aerosol, membebaskan permukaan dan 
peralatan dari infeksi, penggunaan pengaman sekunder, dan mendekontaminasi limbah penular sebelum dibuang.

Ketiga, bekerja dengan bahan kimia yang mudah terbakar. Bahan-bahan kimia ini umumnya menyebabkan kebakaran jika tidak ditangani dengan tepat. Perlakuan-perlakuan tambahan yang dibutuhkan untuk bekerja dengan bahan kimia demikian antara lain: menggunakan bahan kimia seminim mungkin (sesedikit mungkin sesuai kebutuhan), mengurangi atau menghilangkan bahan kimia yang mudah terbakar dan pengoksidasi, penggunaan selimut gas lembam, memisahkan bahan dari operasi dan sumber penyulutan, dan tidak memanaskan zat yang mudah terbakar. Keempat, bekerja dengan cairan mudah terbakar. Hampir sama dengan bahan kimia mudah terbakar, bahan inipun umumnya dapat menyebabkan kebakaran. Perlakuan-perlakuan tambahan yang dibutuhkan untuk menangani bahan demikian, antara lain: menghindari pembuatan konsentrasi uap yang mudah terbakar; wadah tetap tertutup; pelarutan uap yang mudah terbakar dilakukan diruangan berventilasi; pemindahan bahan harus dilakukan dalam tudung kimia laboratorium; pada teknik pelarutan, peralatan yang digunakan harus tahan ledakan; dan saluran pembuangan bahan harus disalurkan kedalam tanah. Kelima, bekerja dengan senyawa reaktif dan eksplosif. Perlakuan-perlakuan tambahan jika bekerja dengan bahan demikian antara lain: penggunaan perangkat pelindung; penggunaan peralatan pelindung diri; pengujian tetesan bahan dengan menggunakan suara yang direkam, pengujian elektrostatis, penentuan kuantitas reaksi, dan melakukan operasi reaksi.

Keenam, bekerja dengan peroksida organik. Senyawa ini merupakan senyawa dengan stabilitas yang sangat rendah sehingga tergolong dalam zat yang paling berbahaya yang biasanya ditangani di laboratorium, terutama sebagai inisiator untuk reaksi radikal bebas. Perlakuan-perlakuan tambahan jika bekerja dengan bahan demikian, antara lain: pembatasan jumlah peroksida hingga jumlah minimal yang dibutuhkan; tidak diperkenankan mengembalikan peroksida ke dalam wadah; mengurangi sensitivitas sebagian besar peroksida terhadap kejutan dan panas dengan melarutkannya dengan pelarut lembam, seperti hidrokarbon alifatik; tidak diperkenankan menggunakan bahan kimia aromatik karena dapat menguraikan diasil peroksida; tidak menggunakan larutan peroksida dalam pelarut yang mudah menguap; tidak diperkenankan menggunakan spatula logam; menghindari sumber api; menghindari gesekan, tekanan, dan segala bentuk benturan didekat peroksida, terutama peroksida padat; dan menyimpan peroksida pada suhu terendah sesuai titik bekunya.

Bekerja dengan peralatan kimia merupakan indikator lain yang harus diperhatikan dalam keamanan kimia. Beberapa hal yang harus diperhatikan jika bekerja dengan peralatan 
kimia, yakni: bekerja dengan peralatan berdaya listrik, bekerja dengan gas mampat, serta bekerja dengan tekanan dan suhu yang tinggi atau rendah. Pertama, bekerja dengan peralatan berdaya listrik. Sebagian besar peralatan kimia terutama peralatan-peralatan analisis umumnya berdaya listrik. Perlakuan-perlakuan umum yang harus diperhatikan jika bekerja dengan peralatan demikian, antara lain: memasang isolasi dengan baik; peralatan listrik dan suplai daya telah terisolasi aliran listriknya; pemasangan lampu anti ledakan; hindari motor lilitan seri; menghilangkan uap mudah terbakar; tidak diperkenankan penggunaan ototransformator variabel untuk mengendalikan kecepatan motor induksi; mengurangi kondensasi; dan mengurangi kemungkinan kejutan listrik. Kedua, bekerja dengan gas mampat. Perlakuan-perlakuan umum yang harus diperhatikan jika bekerja dengan peralatan demikian, antara lain: menghindari regangan dan retakan tersembunyi pada peralatan yang digunakan; tidak memaksakan ulir jika terasa seret; penggunaan lapisan Teflon atau ulir yang sesuai; mengkondisikan semua reaksi di bawah tekanan standar; dan tidak diperkenankan mengisi autoklaf dan bejana reaksi bertekanan lain lebih dari separuh. Ketiga, bekerja dengan tekanan dan suhu yang tinggi atau rendah. Perlakuanperlakuan umum yang harus diperhatikan pada saat bekerja dengan peralatan demikian, antara lain: pengujian tekanan dan kebocoran pada bejana bertekanan; pelepasan gas yang sesuai pada peralatan kaca; penggunaan katup pelepas bertekanan Teflon; penyegelan botol sentrifuga; tidak diperkenankan penggunaan adaptor konstruksi dari tabung kaca atau sumbat gabus; dan tidak diperkenankan operasi peniupan kaca kecuali jika tersedia fasilitas pendingin yang sesuai. Sistem keamanan kimia merupakan sistem keamanan yang kompleks. Sistem keamanan kimia menyangkut beberapa hal, antara lain: penyimpanan bahan, penyimpanan alat, penanganan limbah, bekerja dengan bahan-bahan kimia, dan bekerja dengan peralatan kimia.

\section{METODE PENELITIAN}

Penelitian/survey ini dilaksanakan di Universitas Kristen Indonesia pada oktober 2017. Metode sampling yang digunakan adalah sampling jenuh di mana semua anggota populasi menjadi anggota sampel. Sampel pada penelitian tersebut adalah seluruh mahasiswa Program Studi Pendidikan Kimia Fakultas Keguruan dan IImu Pendidikan Universitas Kristen Indonesia Angkatan 2015-2017. Metode pengumpulan data yang digunakan adalah metode observasi dengan menggunakan angket sikap sadar keamanan kimia mahasiswa. Penskoran angket mengikuti sistem penskoran skala Linkert disertai lima pilihan alternatif jawaban yang diinginkan (dengan interval penilaian 1,2,3,4, dan 5). Angka 1 untuk pilihan kemampuan dasar; angka 2 untuk pilihan diatas kemampuan dasar; angka 3 
untuk pilihan kemampuan menengah; angka 4 untuk pilihan kemampuan mahir; dan angka 5 untuk pilihan kemampuan ahli. Penyebaran angket dilakukan setelah acara webinar dilaksanakan dengan metode random. Angket tersebut tanpa disertai identitas responden untuk menjamin kesahihan data yang dikumpulkan. Acara webinar tersebut diinisiasi oleh Himpunan Kimia Indonesia ( $\mathrm{HKI})$ yang bekerjasama dengan beberapa universitas termasuk Universitas Kristen Indonesia.

\section{HASIL DAN PEMBAHASAN}

Seminar berbasis website atau sering disebut webinar merupakan seminar era modern yang berbasis jaringan internet. Webinar tidak menuntut adanya pertemuan secara langsung, namun hanya berbasis jaringan. Dengan tidak menuntut pertemuan secara langsung, maka webinar memungkinkan dilakukan kapanpun dan di manapun sesuai kesepakatan bersama. Dengan demikian, maka memungkinkan adanya peserta dari berbagai lokasi tanpa bertemu. Secara umum webinar dapat digambarkan sebagai berikut.

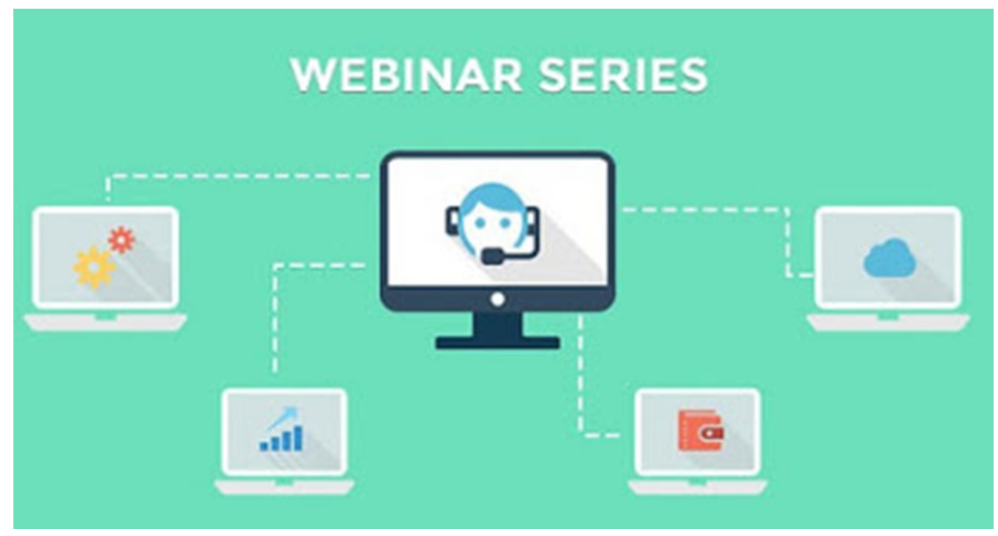

Gambar 1. Alur Seminar Berbasis Website (sumber: www.lupadaratan.com)

Seperti halnya seminar biasa, webinar juga membutuhkan pemateri sebagai sumber informasi yang menjadi bahan diskusi. Perbedaan utama terletak pada peserta seminar, di mana peserta tidak harus berada pada ruang/lokasi yang sama, namun memungkinkan dari beberapa lokasi dengan dihubungkan oleh jaringan (website). Selain lokasi peserta seminar, acara diskusipun sedikit berbeda. Jika di seminar biasa, peserta bisa berdiskusi secara direct/langsung pada pemateri. Tetapi pada webinar, peserta hanya boleh bertanya dengan cara diketik dikolom yang telah disediakan pada website dimaksud.

Berdasarkan hasil pengumpulan data melalui angket yang diberikan sesaat setelah acara webinar selesai, maka diperoleh data sebagai berikut.

Tabel 1. Data Respon Mahasiswa terhadap Sikap Sadar Keamanan Kimia 


\section{Pernyataan}

Pilihan

A. Cara untuk menilai kepatuhan terhadap praktik terbaik

\begin{tabular}{lllll}
\hline 1 & 2 & 3 & 4 & 5
\end{tabular}
keamanan kimia di institusi anda.

B. Cara untuk membedakan antara ancaman dari orang

$\begin{array}{llll}9 & 5 & 4 & 1\end{array}$
dalam dan orang luar.

C. Apa saja yang harus dipertimbangkan saat mendesain

$\begin{array}{llll}7 & 5 & 5 & 2\end{array}$
sistem keamanan fisik.

D. Peran dan tanggungjawab berbagai pemangku $6 \begin{array}{lllll}6 & 6 & 6 & 1\end{array}$ kepentingan dalam managemen resiko.

E. Cara untuk melakukan analisis kerentanan transportasi $\quad \begin{array}{llll}9 & 5 & 5\end{array}$ kimia.

F. Komponen-komponen budaya keselamatan yang kuat $\begin{array}{llll}8 & 6 & 5\end{array}$ di laboratorium kimia.

G. Masalah keamanan fisik primer untuk fasilitas kimia. $\quad \begin{array}{llll}11 & 2 & 6\end{array}$

H. Cara untuk mempromosikan kesadaran keamanan $\begin{array}{lllll}5 & 6 & 8\end{array}$ kimia dalam organisasi anda.

$\begin{array}{lllll}\text { I. Strategi utama untuk menangani resiko kimia. } & 8 & 7 & 4\end{array}$

Keterangan:

$1=$ dasar

2 = diatas pengetahuan dasar

$3=$ menengah

$4=$ mahir

$5=$ ahli

Pengisian angket diikuti oleh 25 orang mahasiswa, di mana 19 responden dinyatakan valid. Mahasiswa-mahasiswa tersebut terdiri dari tiga angkatan yakni, angkatan 2015/2016, angkatan 2016/2017, dan angkatan 2017/2018. Angket terdiri dari Sembilan (9) pernyataan yang berhubungan dengan keselamatan kimia, di mana setiap pernyataan diberikan lima opsi pilihan yang disusun berdasarkan skala Linkert. Kelima opsi tersebut, antara lain: angka "1" untuk opsi pilihan pengetahuan dasar; angka "2" untuk opsi pilihan di atas pengetahuan dasar; angka "3" untuk opsi pilihan pengetahuan menengah; angka "4" untuk opsi pilihan pengetahuan mahir; dan angka " 5 " untuk opsi pilihan pengetahuan ahli. Sebaran persentase respon mahasiswa dapat dilihat pada grafik berikut. 


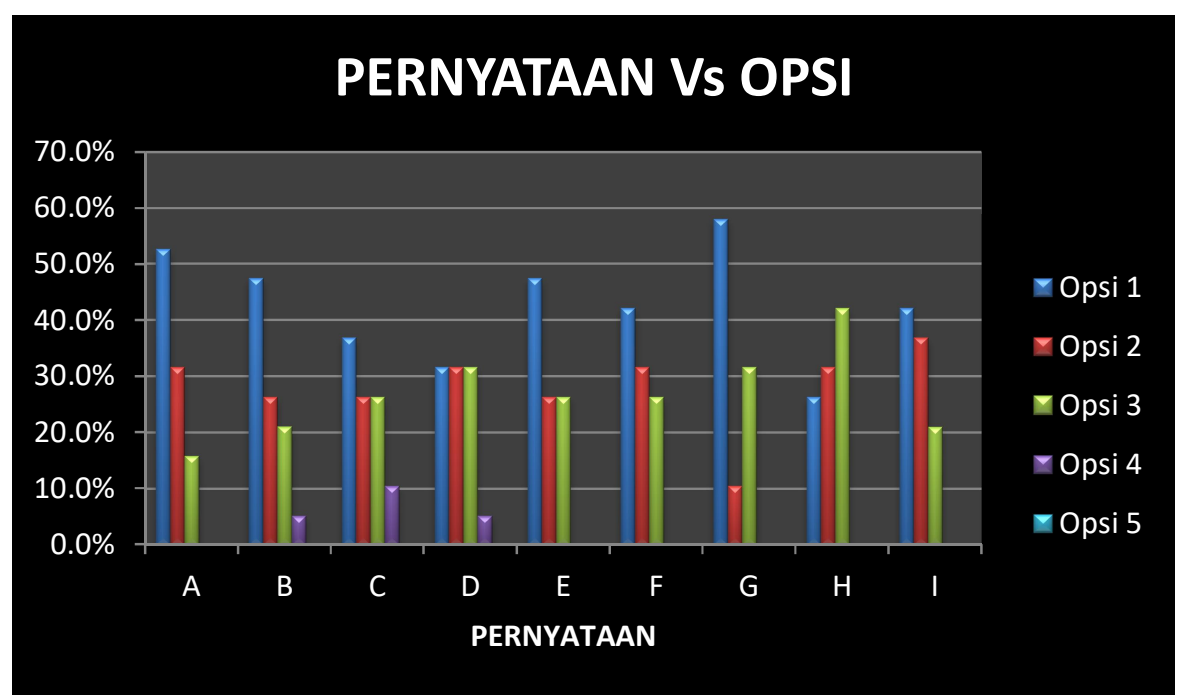

Gambar 2. Persentase Item Respon Mahasiswa Terhadap Pernyataan Keamanan Kimia

Berdasarkan grafik di atas, maka untuk pernyataan "cara untuk menilai kepatuhan terhadap praktik terbaik keamanan kimia di institusi anda", sebanyak 52,6\% responden memilih pada tingkat kemampuan dasar, 31,6\% memilih pada tingkat kemampuan di atas pengetahuan dasar, dan $15,8 \%$ memilih pada tingkat pengetahuan menengah. Berdasarkan data tersebut maka dapat disimpulkan bahwa sebagian besar responden beranggapan bahwa untuk menilai kepatuhan praktik terkait keamanan kimia masih berada pada tingkat pengetahuan dasar. Sementara itu, pada tingkat pengetahuan yang paling tinggi, yakni pada tingkat pengetahuan mahir dan ahli mendapatkan presentase nol dari responden. Data tersebut memberikan gambaran bahwa stakeholder universitas butuh usaha yang lebih baik lagi pada penilaian kepatuhan praktik terkait keamanan kimia.

Pengetahuan membedakan ancaman dari orang dalam dan orang luar memiliki persentase yang lebih baik jika dibanding dengan menilai kepatuhan keamanan kimia. Sebanyak 47,4\% responden memilih pengetahuan dasar, 26,3\% memilih di atas pengetahuan dasar, $21,1 \%$ memilih pengetahuan menengah, dan 5,2\% memilih pengetahuan mahir. Pada pernyataan desain sistem keamanan fisik, 36,9\% responden memilih pada pengetahuan dasar, $26,3 \%$ memilih pada kemampuan diatas pengetahuan dasar, 26,3\% memilih pengetahuan menengah, dan 10,5\% memilih pada pengetahuan mahir. Pada pernyataan, peran dan tanggungjawab berbagai pemangku kepentingan dalam managemen resiko, 31,6\% responden memilih pada pengetahuan dasar, 31,6\% memilih pada kemampuan di atas pengetahuan dasar, 31,6\% memilih pada pengetahuan menengah, dan 5,2\% memilih pada kemampuan mahir. Pada pernyataan analisis kerentanan 
transportasi kimia, 47,4\% memilih pada kemampuan dasar, 26,3\% memilih pada kemampuan diatas pengetahuan dasar, dan 26,3\% memilih pada kemapuan menengah.

Respon mahasiswa terhadap komponen-komponen budaya keselamatan yang kuat di laboratorium kimia relatif memiliki kemiripan respon pada setiap komponen di mana 42,1\% memilih pada kemampuan dasar, 31,6\% memilih pada kemampuan di atas pengetahuan dasar, dan 26,3\% memilih pada kemampuan menengah. Pada pernyataan masalah keamanan fisik primer untuk fasilitas kimia, 57,9\% memilih pada pengetahuan dasar, 10,5\% memilih di atas pengetahuan dasar, dan 31,6\% memilih pada pengetahuan menengah. Pada pernyataan cara untuk mempromosikan kesadaran keamanan kimia, sebanyak 26,3\% memilih pada pengetahuan dasar, 31,6\% memilih pada kemampuan di atas pengetahuan dasar, dan $42,1 \%$ memilih pada pengetahuan menengah. Pada pernyataan strategi utama untuk menangani resiko kimia, sebanyak 42,1\% memilih pada pengetahuan dasar, 36,9\% memilih pada kemampuan di atas pengetahuan dasar, dan 21,0\% memilih pada pengetahuan menengah.

Berdasarkan data persentase tersebut, terlihat bahwa tidak ada satupun responden yang memilih pada pengetahuan ahli yang merupakan kemampuan tertinggi untuk setiap maupun secara keseluruhan komponen pernyataan. Hal ini tentu harus menjadi perhatian utama agar keamanan kimia dapat terwujud dengan baik. Secara keseluruhan, persentase respon mahasiswa terhadap berbagai komponen, dapat dilihat pada grafik berikut.

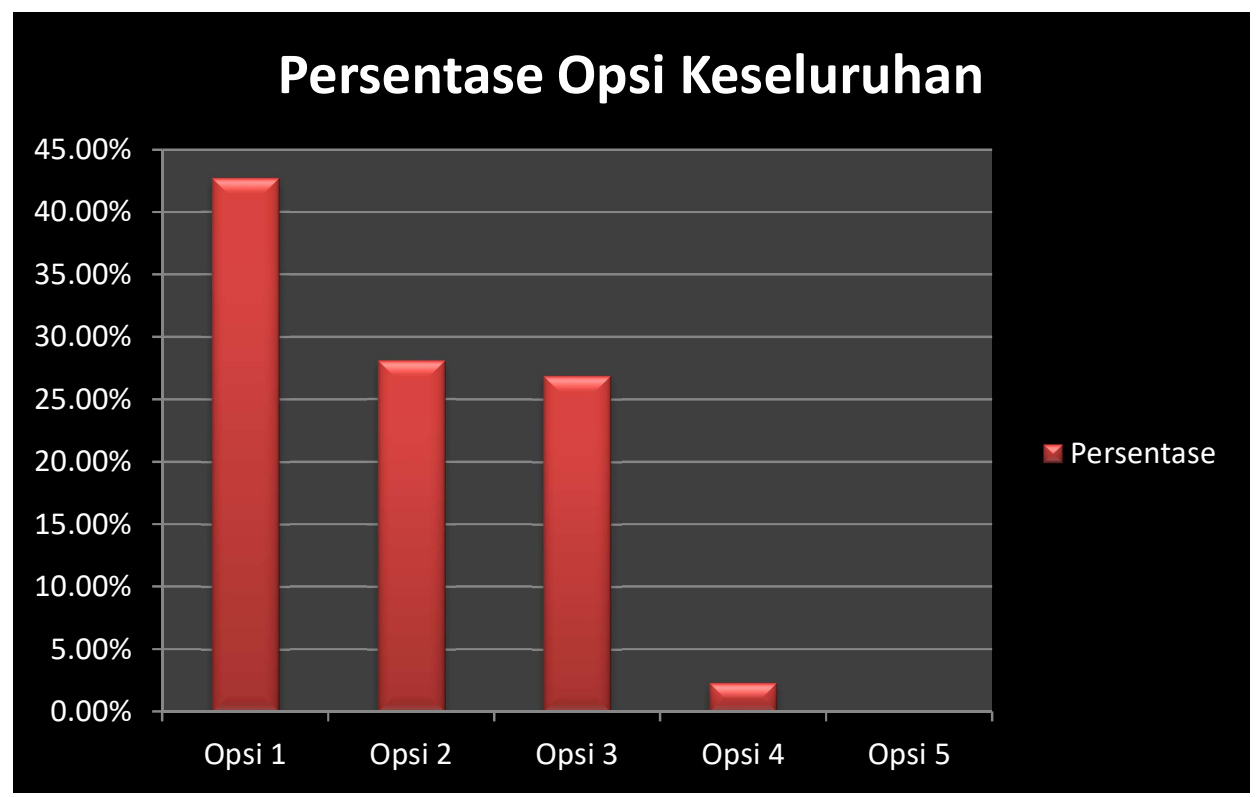

Gambar 3. Persentase Opsi Keseluruhan Terhadap Pernyataan Keamanan Kimia 
Berdasarkan grafik di atas, terlihat bahwa $42,7 \%$ responden memilih kemampuan pada pengetahuan dasar untuk seluruh komponen penilaian. 28,1\% memilih kemampuan diatas pengetahuan dasar untuk komponen keseluruhan, 26,9\% memilih pada pengetahuan menengah, dan $2,3 \%$ di antaranya memilih pada kemampuan mahir untuk seluruh komponen penilaian. Dari data tersebut terlihat bahwa mayoritas responden beranggapan bahwa sikap sadar keamanan kimia berada pada kemampuan pengetahuan dasar.

\section{KESIMPULAN}

Berdasarkan hasil penelitian di atas, maka dapat disimpulkan bahwa sikap sadar keamanan kimia menurut mahasiswa sebagian besar berada pada tingkat pengetahuan dasar sebesar 42,7\%. 28,1\% lainnya merespon pada tingkat diatas pengetahuan dasar. 26,9\% berada pada tingkat pengetahuan menengah. Dan 2,3\% berada pada tingkat pengetahuan mahir. Untuk pengetahuan pada tingkat ahli yang merupakan pengetahuan tertinggi, mahasiswa tidak memberikan respon. Data tersebut menunjukkan bahwa sikap sadar keamanan kimia tergolong rendah. Solusi yang paling mungkin diambil adalah diperbanyaknya pelatihan, baik pelatihan secara langsung maupun pelatihan dengan cara seminar maupun workshop.

\section{ACUAN PUSTAKA}

Dantjie, P.R., Baju, W., Suroto. (2016). Perbedaan Pengetahuan, Sikap, dan Praktik Keselamatan dan Kesehatan Kerja Laboratorium antara Mahasiswa Program Studi D3 dan S1 pada Institusi Pendidikan di Semarang. Jurnal Kesehatan Masyarakat, $4(2)$.

Harefa, N., (2018). Hubungan Motivasi Belajar Terhadap Keterampilan Pemecahan Masalah Siswa Pada Metode Praktikum. Jurnal Selaras, 1(1) pp. 28-38.

Moran, L., dan Tina, M., (2010). Keselamatan dan Keamanan Laboratorium Kimia. Washington: National Research Council.

Sangi, M.S., Adey, T., (2018). Keselamatan dan Keamanan Laboratorium IPA. Jurnal MIPA UNSRAT, 7(1).

https://www.lupadaratan.com/2017/06/webinar-era-baru-dari-seminar-berbasis.html. Diakses, 19 Maret 2019. 
JDP Volume 12, Nomor 1, April 2019: 17-28 